\title{
The Military And the Family As Greedy Institutions
}

\author{
MADY WECHSLER SEGAL \\ University of Maryland
}

\begin{abstract}
$\mathrm{n}$ institution is a set of interrelated norms and roles governing some area of social life. The study of military families involves analysis of how two societal institutions-the military and the family-intersect. Both make great demands of individuals in terms of commitments, loyalty, time, and energy: they therefore have some of the characteristics of what Coser calls "greedy" institutions.'

This paper contends that, due to various social trends in American society and in military family patterns, there is greater conflict now than in the past between these two greedy institutions. Further, the ways in which they respond to this competition for the service member's commitment are already affecting and will to continue to affect how far the military moves in an institutional or occupational direction, as described by Moskos. ${ }^{2}$ However, there can be changes within the traditional military institution without the military becoming less institutional and more occupational in Moskos' sense of these terms.
\end{abstract}

AUTHOR'S NOTE: An earlier version of this paper was prepared for a conference on "Institutional and Occupational Trends in Military Organization" held at the Air Force Academy in June 1985. The Air Force provided support for that conference to Northwestern University. I appreciate the helpful comments made on that draft by Norman Goodman, Nicholas A. Jans, Franklin D. Margiotta, James A. Martin, Charles C. Moskos, Joseph M. Rothberg, David R. Segal, and H. Wallace Sinaiko.

ARMED FORCES \& SOCIETY, Vol. 13 No. 1, Fall 1986 9-38

$\circlearrowleft 1986$ by the Inter-University Seminar on Armed Forces and Society 


\section{The Nature of Greedy Institutions}

Both the military and the family, like other social institutions, depend for their survival on the commitment of their members, for whose participation and loyalties they compete with each other and with other social groups. Lewis Coser describes this competition:

Organized groups are always faced with the problem of how best to harness human energies to their purposes. They must concern themselves with mechanisms which insure that people will be sufficiently motivated to be loyal even in the face of competing appeals from other sources within the wider social structure.

Such competition for loyalty and commitment is a perennial problem because these are scarce resources. Not only do human beings possess only finite libidinal energies for cathecting social objects, but their resources of time are similarly limited. As a consequence, various groups having a claim on individuals' energies and time compete with one another in the effort to draw as much as they can, within normative limits, from the available pool of resources. ${ }^{3}$

Coser notes that individuals can meet competing demands because "modern social institutions tend to make only limited demands on the person,", and because "this multiplicity of claims is patterned and channeled through normative regulations and preferences." ${ }^{, 5}$ He illustrates this with the example of how the demands of work and family can be reconciled: "the amount of time that an individual legitimately owes to his employer is normatively and even legally established; this makes it possible for him to have time for his family or other nonoccupational associations." 6

These normative and legal limitations on employers' demands are relatively recent. Historically, employers often had greater control over their employees' time. This was certainly true under feudal systems, but it also characterized systems of apprenticeship. Even after industrialization, prior to the trade union movement and legislative restrictions, factory owners controlled the working conditions of their employees; they could and did require long hours. The "company town" was distinguished by one employer not only controlling the work lives of residents, but also exercising greater control over the nonworking 
hours of employees. The trade union movement brought about guarantees of better working conditions and negotiated and legislative restrictions on the working hours employers could exact from employees. In contrast, unionization of the American military has been statutorily precluded.

In today's differentiated society, individuals move from one sphere of life to another, with each sphere limited in the claims it can make on the individual's time and energy. Despite these limitations, however, some modern institutions are "greedy":

Yet the modern world, just like the world of tradition, also continues to spawn organizations and groups which, in contradistinction to the prevailing principle, make total claims on their members and which attempt to encompass within their circle the whole personality. These might be called greedy institutions, insofar as they seek exclusive and undivided loyalty and they attempt to reduce the claims of competing roles and status positions on those they wish to encompass within their boundaries. Their demands on the person are omnivorous. ${ }^{7} .$. Greedy institutions are characterized by the fact that they exercise pressures on component individuals to weaken their ties, or not to form any ties, with other institutions or persons that might make claims that conflict with their own demands. ${ }^{8}$

Coser distinguishes between his concept of greedy institutions and Goffman's concept of "total institutions." Goffman defines a total institution as "a place of residence and work where a large number of likesituated individuals, cut off from the wider society for an appreciable period of time, together lead an enclosed, formally administered round of life." "While this description is most often associated with prisons and mental hospitals, Goffman actually differentiates several types of total institutions according to their purposes. He also uses army barracks and ships as examples of total "institutions purportedly established the better to pursue some worklike task and justifying themselves only on these instrumental grounds." ${ }^{10}$ In fact, many of his examples come from military situations, primarily military entry training, enlisted barracks, and ships-contexts where families are excluded.

While recognizing "evident overlaps between 'total' and 'greedy' institutions," Coser distinguishes between them. He notes that "Goffman focuses on physical arrangements separating the 'inmate' from the 
outside world." In contrast, Coser shows that "greedy institutions, though they may in some cases utilize the device of physical isolation, tend to rely mainly on non-physical mechanisms to separate the insider from the outsider and to erect symbolic boundaries between them." "

While the military and the family may not possess in extreme form all the characteristics Coser identifies for greedy institutions, they fit the concept well enough to make it useful in analyzing military families.

Coser notes that social change sometimes makes meeting competing demands more problematic:

During the process of social differentiation, tensions and conflicts develop precisely where a new normative pattern for differential allocation of time and energy has not yet been established. ${ }^{12}$

I contend that the current competition between the military organization and the family is occurring in a period of such social change without an established normative pattern and that it will lead to new normative patterns for resolving the conflicts. The potential outcomes of this institutional adaptation process can be analyzed in terms of the institutional/occupational model of military organization by exploring whether they move the military organization in a more institutional or occupational direction. It is important to recognize, however, that the change may be from one institutional form to another.

For institutions, and groups and organizations within them, to survive in the face of competing demands on individuals, they must develop mechanisms for motivating individual participation and commitment. In the institutional military, as described by Moskos, individual commitment and self-sacrifice is legitimated through the operation of normative values, which compel the individual to accept great demands on his time and energy. Further, the organization controls the demands: the individual does not get to choose when and how to comply. Role obligations are diffuse, and place of residence is not separated from place of work. In return for his service, the individual receives esteem from the larger society and compensation from the military, much of it in noncash form. Of the several types of nonmonetary compensation, those that have the greatest relationship to families are job security, on-base housing, medical care, allotments by family size, subsidized on-base consumer facilities, and numerous on-base services, such as schools and recreational activities.

To accomplish its mission, the military makes various demands on 
service members. While it exerts some specific normative pressures directly on family members, most pressures affecting families are exerted indirectly through claims made on the service members. For both types of pressures, the family is expected to adapt to the greediness of the military institution and support the service member in meeting military obligations. However, important societal trends in general and in military family patterns in particular are making this adaptability problematic. Because of these trends, which include changes in women's roles in society (especially labor force participation rates), as well as increases in the numbers of married junior enlisted personnel, sole parents, active duty mothers, and dual-service couples, military families themselves are becoming greedier, increasing the potential conflict between the military and the family.

To clarify the conflict, the ways in which the family operates as a greedy institution, especially for certain people, will be examined. Second, the military will be analyzed as a greedy institution; and the specific demands it makes-and some effects those demands have-on service members and their families will be described. Third, the trends that lead to increased conflict will be detailed. Fourth, actual and potential adaptations of the military to family trends will be discussed.

\section{The Family as a Greedy Institution}

Nuclear families make different demands on different members. All members are expected to be emotionally committed to the family, to display affection toward other members, to identify with the family as a unit, and to fulfill role obligations that are diffuse relative to most other social groups. However, the family is not a greedy institution for all members; or, rather, if we use the concept of greed as a continuous dimension, the family is greedier for some members than for others.

Lewis Coser and Rose Coser note that the family is greedy for women and discuss recent changes in the normative legitimacy of this greed..$^{13}$ They find it is not the husband but the wife "who is expected to devote most of her time, as well as her emotional energies, to their family." ${ }^{14}$ They discuss how housewives are expected to maintain exclusive attachment to the family and to make sacrifices for it. For example, as both cause and consequence of the greediness of the family, women have been excluded from high-status occupations because such occupations require commitments that would interfere with the fulfillment of family obligations.

The insights Coser and Coser provide into the dynamics of the con- 
flict between family demands and occupational requirements for professional women can be applied to other persons as well. This conflict

is one of allegiance, and it does not stem from the mere fact of involvement in more than one social system. Such conflicts do not typically arise in the case of husbands. Men can be fully engaged in their occupations without fear of being accused of a lack of devotion to their families. It is only when there is a normative expectation that the family will be allocated resources of time, energy, and affect that cannot be shared with other social institutions that conflict arises. And this typically occurs only in the case of women who have the cultural mandate to give primary allegiance to their families. ${ }^{15}$

While this conflict is generally greater for women, it occurs for men as well, to the extent that their work interferes with their ability to provide the normatively expected resources of time, energy, and affect to the family. This happens when either the family is relatively greedy or the work itself is so greedy that it interferes with the fulfillment of relatively minimal family demands.

At certain stages, of course, the family is relatively greedy for both women and men. This is the case, for example, with new marriages, which require greater time and emotional adjustment than established relationships, and with children who are very young or who for other reasons need fairly constant supervision. As children get older, they need less constant supervision; however, parents of adolescents often find this stage demanding emotional energy. And, clearly, the family is especially greedy when there is only one parent.

Moreover, while care of children and household tasks have been traditionally considered women's work, fathers never have been absolved from all family responsibilities, and social changes are increasing their normative share. Witness how the housewife role is becoming a much less exclusive role for women. The past 20 to 30 years have witnessed a virtual revolution in women's labor force participation; today, a majority of American women, including those with preschool children, are in the labor force. Legislation has removed many educational and occupational barriers to women, increasing their access to high-status positions. Coser and Coser discuss the effects these changes have on the greedy family: 
As long as [the] "greedy" famil[y] could rely in the main on housewives who accepted with equanimity their unequal position of power, it could operate with a minimum of friction, even though it seems often to have exerted a high toll in psychic stress and emotional disturbance. But once women began to realize that there existed realistic chances of achieving more nearly equal status with their husbands if and when they involved themselves in the upper reaches of the occupational and professional world and so acquired new resources, the "greedy" family was in trouble. ${ }^{16}$

Looking toward the future, Coser and Coser envision a time when, as a result of both more flexible work schedules and decreased household tasks, the pattern of women's work and family roles will resemble men's:

At this point in time, one can begin dimly to foresee a new family constellation in which both he and she are the family's providers, co-managers of the household and true partners in the care of the children so that their respective resources of power are more nearly equal. ${ }^{17}$

The Cosers' vision includes greater continuity between women's lives before and during marriage, which they conclude "will be the death of the 'greedy' family." ${ }^{18}$ While I agree that the family of the future will cease to be greedy in the extreme for women and that overall family demands will decrease, I contend that the more wives resist the greediness of the family and participate in the work world, the greater will be the family demands on men. This increases the potential for conflict not only between husbands and wives, especially during the transition to greater equality between men and women at home and at work, but also between work and family demands for men, especially for those in greedy occupations such as the military. For instance, we can expect pressures from wives on husbands to adapt their career decisions to family needs, including wives' career considerations.

\section{The Military as a Greedy Institution}

The military is unusual in the pattern of demands it makes on service members and their families. While each specific organizational requirement can be found in other occupations, the military is almost unique in the constellation of requirements. (Perhaps the only other occupation that exerts a similar set of pressures is the foreign service.) While 
some demands vary in frequency and intensity among and within the services, over the course of a military career, a family can expect to experience all the specific demands. Characteristics of the life-style include risk of injury or death of the service member, geographic mobility, periodic separation of the service member from the rest of the family, and residence in foreign countries. There are also normative pressures directly on family members regarding their roles in the military community.

\section{Risk of Injury or Death}

The risk that military personnel will be wounded or killed in the course of their duties is an obvious aspect of the institution's demands. The legitimacy for the institution to place its members at such physical risk is perhaps the greediest aspect of all. While this risk is, of course, greatest in wartime, even peacetime military training maneuvers entail some risk of injury, and military personnel can be sent at any moment to areas of armed conflict. The effects on military families of the potential for injury and death in both peacetime and wartime are studied relatively seldom. Therefore, we know less about them than about the effects of other military demands on families. The potential for casualty has been studied as a source of stress during certain kinds of separations. Studies of military families conducted during and after World War II emphasized the impact of wartime separation. Similarly, recent research has focused on the families of American prisoners of war and those missing in action in Vietnam. But there is much less research on the grieving process in families of servicemen who were killed. ${ }^{19}$

\section{Geographic Mobility}

The U.S. armed forces periodically transfer personnel to new locations, for new tours of duty as well as for specific types of training. Both frequency of mobility and length of duty tours vary among the services as a function of organizational policy. Results of the 1978-79 DoD Survey of Officers and Enlisted Personnel show that, across all services,

[twenty-nine] percent of surveyed enlisted personnel have been at their present location less than one year, 36 percent between one and two years, and 21 percent between two and three years. Among officers, 33 percent have been at their present location less than one year, 33 percent between one and two years, and 22 percent between two and three years. ${ }^{20}$ 
Thus, 86 percent of enlisted personnel and 88 percent of officers had moved at least once in the three years preceding the survey.

First-term personnel were included in the above figures, and the move to their first assignment was counted. Doering and Hutzler also report on the number of "permanent changes of station" (i.e., "a transfer for a regular tour of duty as opposed to a temporary reassignment'") service personnel and their families experienced throughout their military service. ${ }^{21}$ Those who had been in the military longer had, on average, moved more times. Within categories of length of service, officers had more permanent changes of station than enlisted personnel. Regardless of length of service, however, 54 percent of enlisted people and 75 percent of officers reported moving at least three times; for those with just seven to ten years of service, the corresponding figures are 76 percent and 82 percent, respectively. For those with more than fourteen years of service, 40 percent of enlisted personnel and 55 percent of officers reported more than nine moves.

Families of military personnel move less often than the service members themselves, but relocation is still frequent, especially for officers' families. For all personnel, regardless of length of service, the percent reporting at least three family moves was 43 percent for enlisted and 69 percent for officers; for those with seven to ten years of service, the corresponding figures are 41 percent and 59 percent, respectively. For enlisted personnel who had been in the military for more than fourteen years, 9 percent reported that their spouse or children had moved more than nine times; the corresponding figure for officers is 31 percent. $^{22}$

While many service members and their spouses view the opportunity to travel as a benefit of military service, geographic mobility is also seen as a hardship that disrupts family life and necessitates adjustments under the best of circumstances. ${ }^{23}$ The most obvious component of geographical mobility is the requirement to move frequently. Less obvious and less often discussed in the literature on military families is the first move, which perhaps calls for the greatest adjustment. Whether a service member is already married when entering the military or marries later, the spouse's first residence during military service is usually away from home. This has special implications for young enlisted families because it is likely to be the first time they are away from their families of orientation and long-term friends. In contrast, junior officers are older and have gone to college, often away from home. Similarly, officers' spouses are more likely than enlisted spouses to have gone to college ${ }^{24}$ though they too (like enlisted spouses) may be away from 
their extended families for the first time. All, however, are geographically separated from their usual interpersonal networks and sources of social support. If they manage to become integrated into new supportive networks, these relationships are severed when they are required to move to a new location, an experience that is repeated with each additional move.

The United States is geographically large compared with most other countries. Therefore, moves generally take a family relatively large distances, making contact with family and friends more difficult.

Besides the social disruption of moving are the other adjustments to a new location. The place is unfamiliar and one must learn one's way around. For families with limited resources and/or small children, this can be especially stressful. Junior enlisted families often must make do without a car or access to public transportation. The physical environment and climate may also be quite different from what the family members are accustomed to. Whatever the type (including size) of the community, some military families will be used to another type. For example, people from rural areas often find large military installations intimidating; they are unaccustomed to living close to neighbors. The regional dialect may also be unfamiliar to them, straining communication with others and possibly making them feel like outsiders. ${ }^{25}$

With repeated moves, these adjustments may become easier for some families. However, others who adjust well to earlier moves tire of moving and prefer to settle down.

Moving affects families differently, depending on where they are in the life cycle. Those early in their military careers (especially enlisted personnel) have the least control over when and where they move. They also have the fewest military institutional supports, such as family housing on post. For children in school, moving disrupts their education; the lack of standardized curricula among states can cause gaps or repetition in what they are taught. Moving can be particularly stressful for teenagers. ${ }^{26}$ Adolescence involves a search for personal identity, which usually requires integration into a peer group; moving not only disrupts relationships with peers, but also hampers participation in extracurricular activities, which may be an important component of one's self-concept.

Moving is especially harmful to spouses' employment possibilities and career continuity. Unemployment rates are substantially higher for military than civilian wives. ${ }^{27}$ Family income is lower in military families than civilian families, ${ }^{28}$ due largely to lack of employment opportunities for wives. For officers' wives, who are more likely to 


\section{Mady Wechsler Segal}

be oriented to a career rather than just to employment, geographic mobility interferes with normal career progression. Even if they can find work in their field, they lose seniority when they move. Thus, employment problems create economic hardships for the family and problems of personal identity and worth for the wives.

While the military provides subsidies for moving expenses when a service member is transferred to a new location, these are often inadequate, forcing the family to pay some of the expenses ${ }^{29}$ For both officer and enlisted families, the frequent moves leave them less likely than civilian families to own their own home, which is not only a cultural goal in American society, but also is often a family's major financial asset.

\section{Separations}

Military demands often necessitate that service members be away from their families. The extent and nature of these requirements vary among and within the services. In peacetime, the most common types of assignments that result in family separations include military schooling, field training, sea duty, and unaccompanied tours. There are also assignments on which the family is allowed to accompany the service member but for various reasons chooses not to. The length of peacetime separations generally varies from a few days to a year; wartime separations can be much longer and indefinite. Certain military units (e.g., submariners and the 82d Airborne Division) experience frequent or prolonged separations.

Hill reports that 75 percent of families of career military personnel "have experienced one or more prolonged periods of father absence. ${ }^{, 30}$ At the time of the 1978-79 DoD survey, 15 percent of all married enlisted personnel and 5 percent of officers reported that they were not accompanied by their families. Among the services, separation rates were lowest in the Air Force (8\% of enlisted, $4 \%$ of officers) and highest in the Marine Corps (23\% of enlisted, $10 \%$ of officers). ${ }^{31}$

These proportions of unaccompanied personnel do not include separations caused by temporary duty and field training. Thus, at any one time, the proportions of service members who are away from their families are much higher. Results of the 1978-79 DoD survey show that, of those with spouses and/or children, 55 percent of enlisted and 63 percent of officers had been separated from their families for some time during the year preceding the survey, including 25 percent of enlisted and 29 percent of officers who had spent at least five months away from their families. Navy and Marine Corps personnel (both 
enlisted and officer) had spent more time separated from their families than Army and Air Force personnel. ${ }^{32}$

Some effects of separations on families vary depending on the type of separation, while others are common to most, if not all. Separations always require adjustments by service members and their spouses and children. Since little attention has been given to service members either in research or in the provision of services, we know less about their reactions to separations than about those of their wives. The most common problems experienced by the latter are loneliness, problems with children, physical illness, and loss of their usual social role in the community. ${ }^{33}$ The wife is thrust into the role of sole parent. Research on military children with psychological problems has often identified the absence of the father as a contributing factor. ${ }^{34}$ Even when families cope well with separation, they still view it as a stressful experience requiring adjustment.

Wartime separation carries special problems and sources of stress. Concern for the service member's safety can be paramount. Research on the families of prisoners of war and those missing in action shows that families often go through the stages of grief, but they cannot complete the process and return to normal lives because they are "in limbo., ${ }^{35}$

The reunion process is clearly stressful for families who have been separated for a long time and/or for returning prisoners of war. While less severe for peacetime separations, reunion requires readjustments under the best of circumstances and can precipitate family problems, including family violence. Ironically, some evidence shows that certain successful strategies for family coping during the separation result in greater difficulties reintegrating the service member into the family after it. ${ }^{36}$

The strains of separation may be especially difficult at certain stages of family life. Newly married couples, who have had less time to solidify their relationships, are vulnerable to the disruption of separation. Men who are away during their wives' pregnancy and/or childbirth miss an important family event. Service members separated from their young children miss periods of rapid growth and change in their children. Similarly, they sometimes are absent for special events in their children's lives (e.g., a child's first step, first word, first ride on a bicycle, birthday; an adolescent's participation in competitive athletic events, graduation from high school). Family separation during children's adolescence may also interfere with parent-child relationships and, therefore, with the adolescent's psychological development. In general, such absences 
can cause distress for the service family; sometimes family members harbor long-term feelings of resentment and abandonment.

Separations also have potentially beneficial effects. They allow for individual growth and for development of the marital relationship. Some relationships benefit from a period of less intense interaction. Military members and their spouses sometimes say a separation makes them appreciate each other more and adds novelty and romance to their relationships. But the difficulties of separation are usually seen to outweigh the benefits.

\section{Residence in Foreign Countries}

Because of the United States' role in the balance of world power, even in peacetime, substantial proportions of American military personnel are stationed overseas. The numbers of troops in particular places vary as a function of U.S. foreign policy and world events. As of 31 March 1984, 39 percent of all military personnel were stationed outside of the continental United States; 25 percent were stationed outside of the U.S. states and territories. The corresponding figures for the Army were 39 percent outside the continental United States and 34 percent outside the U.S. states and territories. ${ }^{37}$

From the 1978-79 DoD survey, Doering and Hutzler report on the number of years military personnel had spent in overseas duty according to length of service. Across all services, 59 percent of enlisted personnel and 56 percent of officers with one to six years of service had spent at least one year overseas. For those with seven to ten years of service, the corresponding figures are 90 percent and 80 percent, respectively. Comparisons across military services show that, among personnel with between one and six years of service, the percentage of enlisted personnel with at least one year overseas is largest for the Navy (90\%) and smallest for the Air Force (51\%); for officers, the Army has the largest percentage $(73 \%)$ and the Marine Corps the smallest $(47 \%) .{ }^{38}$

Periodic foreign assignments bring to the military family both benefits and hardships. All the relocation adjustments (described above under ' 'Geographic Mobility") are experienced in extreme form. While they vary according to how different the host culture is from American society, even in those most similar to the United States (industrialized Western democracies) the initial reaction is often one of "culture shock." Behavioral norms differ on matters both serious and mundane; language barriers can lead to feelings of isolation and even fear. ${ }^{39}$

While most families eventually cope with living abroad - and many thoroughly enjoy the experience-some encounter severe difficulties. 
Economic problems are prevalent when the foreign currency exchange rate is unfavorable to the U.S. dollar. Spouses have difficulty obtaining employment. Families who are not command-sponsored-that is, those who are not provided with such support as transportation to the location for family members or housing on post (mostly junior enlisted families)-must live "on the economy" and tend to be isolated from formal and informal military institutional supports. Even for families who are eligible for it, on-post housing may not be available at the beginning of the service member's tour of duty. Thus, the family must either make two moves (the first to off-post housing) or experience family separation; with the latter option, adjustment to the foreign culture is coupled with reunion adjustments.

\section{Normative Constraints}

While the demands on military service members impact indirectly on family life, the military also exercises more direct constraints on families through normative pressures on the behavior of spouses and children. Family members informally carry the rank of the service member, and behavioral prescriptions vary accordingly. In the traditional institutional military, wives of service personnel " are expected to initiate and take part in a panoply of social functions and volunteer activities. ${ }^{, 40}$ Wives of officers and senior noncommissioned officers are integrated into a military social network with clearly defined role obligations and benefits determined by their husbands' ranks and positions.

Wives are socialized through various mechanisms. Traditional expectations are clearly spelled out in handbooks, such as Nancy Shea's The Army Wife, ${ }^{41}$ which covers military customs, rank courtesy, entertaining, etiquette, calling cards, etc. Wives are informed that their husbands owe their primary loyalty to the military, not the family:

Early in your new role as an Army wife you must understand that your husband's "duty" will come first-before you, before your children, before his parents, and before his personal desires and ambitions, ${ }^{42}$

Wives are told how to act at military social functions and are given "tips and taboos." ${ }^{43}$ There are special prescriptions regarding rank:

Although there is no rank among these wives, still a junior officer's wife should always show deference to older women 
and especially to the commanding officer's wife, though not in a way that smacks of "bootlicking" or currying favor.

Additionally, various social obligations are specified:

It is every wife's duty not only to join, but to take an active interest in the wives' club on the post where her husband is stationed. ${ }^{45}$

While some of these prescriptions do not carry the normative force they have had traditionally, most are still communicated and enforced through informal interpersonal processes.

Family members learn that their behavior is under scrutiny and that the degree to which it conforms to normative prescriptions can affect the service member's career advancement. Social pressures are especially exerted on officers' wives and, to a lesser extent, on senior NCO wives. For enlisted wives and for military children, there are fewer prescriptive obligations; rather, pressures on them are more proscriptive in nature. Enlisted wives are generally not required to engage in military community activities; they are expected, however, to refrain from "'troublesome" behavior. Violations of such norms by enlisted wives or by children that come to the attention of military authorities result in pressure on the service members to control their family members. Such pressures are most likely for families who live on military installations because they are more subject to military control and attention than are those who live off post.

While military wives may experience normative constraints as pressures, wives also benefit when they are incorporated into the military system. With their roles institutionalized, wives have defined social identities and are more readily integrated into supportive social networks. Such integrative social mechanisms are likely to make important contributions to personal well-being, especially during stressful times such as routine family separations, relocation, and combat deployment.

\section{Military Family Patterns}

The demands of the military organization (discussed above) require certain kinds of adaptation from military families. Spouses and children must be willing to move when the service member is transferred. Families must be willing to endure separations; spouses must be willing, available, and able to perform the family roles vacated by the absent 
service member. Military social and volunteer activities depend on the participation of officers' wives.

Conflict between military requirements and family needs is avoided when the family adapts to the military's demands. However, family patterns of U.S. military personnel have changed dramatically over the past century; the past 15 years have seen further changes. Most notable (in that it characterizes the largest number of personnel) has been the increase in the proportion of military men who are married, especially in the enlisted ranks. The proportion of active duty women has increased substantially; those who are married to military men enlarge the number of "dual-service" couples. The number of "sole parents" - that is, currently unmarried men and women with minor children-has also grown. Further, civilian wives of military men are being greatly affected by changes in the roles of women in American society that include, most notably, personal identities increasingly independent of husbands and higher rates of labor force participation. All these trends have meant a larger proportion of personnel for whom the family is greedy, and, by normative definitions, legitimately so. And this, in turn, means a heightened potential for conflict between the military and the family.

\section{Marriage}

Goldman summarizes the marital status of military men during the late nineteenth and first half of the twentieth centuries:

Because of military regulations and practices, the majority of active-duty personnel at the turn of the century were unmarried; those who were married were predominantly older officers. Until World War II, "military wife" was synonymous with "officer's wife," since few enlisted men were married, and, if married, their families were of little concern to the institution. However, it was considered a necessity for an officer above the age of 30 to have a wife, since she filled an important role in his social life. ${ }^{46}$

Goldman describes the regulations prohibiting married men from enlisting in the Army and the deplorable living conditions, and uncertain futures for enlisted men, that discouraged military men from marrying and married men from remaining in the service. ${ }^{47}$

The proportion of married military men rose steadily after World War II. From 1953 to 1960 , the percent of all active duty servicemen who were married rose from 38 percent to 52 percent. This proportion 
declined during the Vietnam era to a low of 46 percent in 1968, reflecting the increased number of young unmarried men taken into the services. From 1970 to 1974 , the percent of uniformed men who were married rose from 52 percent to 57 percent; ${ }^{48}$ by 1978,60 percent of all military personnel were married. ${ }^{49}$

Increases in marriage rates are most notable among the enlisted ranks. The percent of enlisted personnel who were married rose from 33 percent in 1953 to 48 percent in 1960 , fell to 39 percent in 1967 , and was back up to 47 percent in $1970 .^{50}$ This marriage rate has continued to rise since 1970: to 50 percent in 1972, 53 percent in $1974,{ }^{51}$ and 58 percent by $1978 . .^{52}$

The percent married is, of course, smaller at the lower ranks, but even among the three lowest enlisted pay grades (E-1 to E-3), it totaled 25 percent in 1978, varying from a low of 17 percent in the Navy to a high of 39 percent in the Air Force. By the time they reach E-5, 68 percent of all active duty enlisted personnel are married, including a majority in each service: 54 percent in the Navy, 59 percent in the Marine Corps, 70 percent in the Army, and 82 percent in the Air Force. ${ }^{53}$ The proportion of military males who are married is higher than for civilian males of the same age..$^{54}$

Among officers, 78 percent of those in all services were married in 1978. At the lowest officer pay grade (0-1), 50 percent were married; by the grade of $0-3$ (captain in the Army), 81 percent were married..$^{s}$

Thus, the American military has increasingly become a married military. This trend, which embraces majorities of the middle and upper ranks and substantial minorities of even the lowest ranks, represents a highly significant change in the nature of enlisted life in the armed services. Since married enlisted personnel do not live in the barracks, barracks life has lost some of its character as a total institution. Further, since junior enlisted personnel are generally not eligible for family housing on the base, they live off post, which draws much of their lives away from the military installation. Thus, there is a great potential for conflict between the greedy military institution's demands on junior enlisted personnel and the generally greedy demands of new marriages, which require intense interpersonal and psychological work.

\section{Military Women}

The number of military women has varied greatly, but the percentage has always been small. The largest number and concentration of women in the U.S. military, until recently, occurred in 1945, when 
approximately 265,000 women made up 2.2 percent of the force of over 12 million. During the 1950s and 1960s, women constituted less than 2 percent of uniformed personnel. ${ }^{56}$

Over the past 15 years, the number and percentage of women in the U.S. military have increased dramatically. At the end of fiscal year 1971, about 30,000 enlisted women and 13,000 female officers together constituted 1.6 percent of the total active duty military. By the end of 1980 , about 151,000 enlisted women (8.6\% of enlisted strength) and 22,000 women officers $(7.9 \%$ of all active duty officers) made a total of 173,000 in uniform ( $8.5 \%$ of the total active forces).

As of March 1984, 198,908 enlisted women (9.4\% of enlisted strength) and 27,531 women officers (9.2\% of all officers) added up to 226,439 women in uniform. The Air Force has the largest representation (11\% of enlisted personnel and $10 \%$ of officers) and the Marine Corps has the smallest $(5 \%$ of enlisted personnel and $3 \%$ of officers)..$^{57}$

While women are still a small minority among military personnel, their presence in previously all-male military situations can potentially change the nature of social and interpersonal dynamics in those situations and may require institutional adaptations. Most relevant to analysis of military families is that the family has been normatively greedier for women than for men. For example, women have been expected to move where their husbands' jobs take them. But since military women, like military men, have less control than most civilians over where they will live, they are unable to conform to traditional family expectations. The institutional adaptations here may come from the family as well as the military, with the family becoming less greedy for women.

Military women are less likely than military men to be married and to have children. ${ }^{58}$ In the Navy, for example, where Navy wives with civilian husbands constitute about 1.5 percent of total Navy forces, 69 percent of these women have no children. By contrast, among Navy men with civilian wives, only 30 percent have no children. ${ }^{59}$

Married military women are also more likely than married military men to be separated from their spouses due to their military assignments. In the Air Force, for example, among military women married to civilian men, 10 percent of the officers and 36 percent of the enlisted women were geographically separated from their husbands. While these couples constitute only 1 percent of the total force, they account for 35 percent of married women officers and 23 percent of married enlisted women. ${ }^{60}$ This rate of separation caused by military assignments is much higher than for married military men with civilian wives. 


\section{Dual-Service Couples}

A small but growing proportion of military families are in the special category of dual-service couples. These are married couples in which both husband and wife are in the military, either in the same service or in different ones. Data from the 1978-79 DoD survey show that 3.9 percent of married enlisted personnel and 9.9 percent of married officers had spouses in the armed forces. The largest proportion was found among married Air Force officers, 13.1 percent of whom had military spouses. ${ }^{61}$

As of July 1984, there were 15,297 married Army service couples; this number includes Army members married to uniformed personnel of other services. ${ }^{62}$ The percentages of Army personnel married to other active duty service members are reported by rank: 13.7 percent of first term enlisted personnel, 6.5 percent of career enlisted personnel, 10.5 percent of company grade officers, and 4.2 percent of field grade officers. ${ }^{63}$

Orthner and Nelson report that "some 2.5 percent of Navy personnel are married to other military members. In nine out of ten cases, the spouse is a member of the Navy. Most common are marriages between enlisted Navy women and enlisted Navy men." ${ }^{64}$ They also note that about " 47 percent of all married Navy women are in dualmilitary marriages compared with only two percent of Navy men.",65 They find that fully 79 percent of dual military couples have no children. ${ }^{6}$

In the Air Force, dual-service marriages as of 1978 constituted 6 percent of the total force. In only 3.2 percent of these couples was the spouse a member of another armed force. The vast majority of dualservice marriages were between an enlisted man and an enlisted woman. Among married Air Force personnel, 76 percent of the women and 4.5 percent of men had a military spouse. Among all dual-service Air Force couples, 69.4 percent had no children. ${ }^{67}$

Dual-service couples are often seen as a problem for personnel management because most such couples desire "joint domicile," which requires the military to coordinate assignments of two people. There is also concern about the deployability of couples with children because they, like single parents, do not have a civilian spouse expected to assume parental responsibilities.

Separations of dual-service couples due to assignments in different locations are more common than for other married military personnel. In the Army in 1984, 38 percent of dual-service couples were not approved for joint domicile. ${ }^{68}$ In the Air Force in 1978, 12.5 percent 
of all dual-career couples were separated because of different assignments, ranging from 9 percent where both spouses were enlisted personnel in the Air Force to 42 percent of Air Force women married to men in another service..$^{99}$ Interestingly, "when separations by assignment occurred in dual-career military marriages, the children, if any, were as likely to stay with their fathers as with their mothers."

Compared with couples in which one member is a civilian with career aspirations, dual-service couples may actually benefit the military organization in two major ways. First, while personnel assignment systems must be adapted for them, this may be accomplished more easily than coordinating with civilian employment opportunities. Second, and quite germane to the analysis of family effects on institutional and occupational trends in the military, couples consisting of two uniformed members are likely to be more committed to the military way of life and to understand each other's job requirements. As long as the armed forces can accommodate these couples, the military gains two members who are integrated into the organization, potentially reducing rather than increasing military/family conflicts. Orthner finds that "couples in which both the husband and wife are Air Force members are more likely to be happily married than couples with a civilian wife.",71

\section{Sole Parents}

Sole parents (or "single parents") are people who are currently unmarried but have custody of at least one minor child. Most sole parents are divorced or separated, although some have never been married. The proportion of military women who are sole parents is greater than the proportion of military men in that category. However, because military personnel are overwhelmingly male, there are more single fathers than mothers in the armed forces. It should be noted in analyzing trends in parenting among military women that, until 1975, military women (regardless of marital status) who became pregnant were automatically discharged from service. ${ }^{72}$

Doering and Hutzler find that

some 4 or 5 percent of the enlisted males in each Service have dependents but no spouse; among enlisted females, the percentage ranges from about 4 percent in the Air Force to 10 percent in the Army. Among officers, both males and females, the rates for dependents but no spouse never exceed 4 percent. $^{73}$ 
Almost all dependents are children. Orthner and Nelson report that "almost one percent of Navy families are headed by single parents, approximately 4,500 members,", that " 2 out of $3(63 \%)$ single parents are men," and that "nearly four percent of Navy women are single parents compared to less than one percent of the men." 75 For the Air Force, "single parents currently comprise over $1 \%$ of the total force in the Air Force. Three out of four of these single parents are men.", 16

The family is greedy for sole parents because there is not another parent to share in child care responsibilities. Conflict between military service obligations and family demands can therefore occur for these parents. Surprisingly, research specifically addressing this issue tends not to find greater difficulties among sole parents, at least as reported by the service members themselves. In his study of Air Force families, Orthner reports:

Some military leaders have expressed alarm at the rising number of single parents in the services. Among Air Force single parents, concerns about their family stability, work performance, child care arrangements, and Air Force commitments appear to be largely unfounded. Some single parents do have problems, but compared to married couples, Air Force single parents are no more likely to report personal or parental stress, nor are they more likely to report work problems or weak Air Force career commitments. ${ }^{77}$

\section{Changes in American Women's Roles}

Increases in numbers of military women, dual-service couples, and sole parents are important changes in military family patterns. However, these patterns still characterize only a small minority of military families; the majority consist of a military man married to a civilian wife. Therefore, societal changes that affect civilian wives are likely to have the greatest impact on the military. Norms regarding the roles of American women, including wives, have been changing rapidly. Wives' personal and social identities are becoming increasingly independent of their husbands, and women's labor force participation rates have risen. These changes have been affecting military wives and will continue to force changes in military family relationships. Military wives are becoming less willing to adapt to the demands of the greedy military institution.

Data on labor force participation of wives of military men show them catching up to the rates for wives of civilian men but also show 
their having greater difficulty finding employment. Data from the 1978-79 DoD survey show 43 percent of enlisted spouses and 55 percent of officer spouses were in the labor force (working full or part time, or unemployed). ${ }^{78}$ U.S. Department of Labor data on military wives show that "from 1970 to 1983 , the percentage of working military wives increased from 30.5 to 47.6 percent." 79 However, the unemployment rate is much higher for military wives than civilian wives: in 1983, 17.2 percent of military wives seeking jobs were unemployed compared with 6.8 percent of civilian wives. ${ }^{80}$ In March 1984, military wives had a jobless rate of 17 percent, more than three times the national rate of 5.3 percent. $^{81}$

Geographical relocation resulting from military transfer is a major obstacle to employment and career mobility for civilian wives of military men. Coser and Coser discuss the role wives of middle-class civilian men play in their husbands' mobility:

The high degree of mobility, both social and geographical, in the careers of middle-class Americans is predicated to a large extent on the readiness of the wife to assume the responsibilities and inconveniences involved in such moves. It is she who bears the major burdens of residential uprooting and social dislocation. Without her contributions as shock absorber, tension manager, and general superintendent, and without her readiness not to be career-bound herself, the mobility chances of her husband would be sharply reduced. The functionalist argument that chances for achievement and upward mobility in American society are well served by the fact that the extended family has been replaced by the nuclear family is indeed correct; but it fails to spell out that the nuclear family is functional for mobility only as long as wives are willingly submitting to its greedy demands. ${ }^{82}$

As military wives become less willing to submit to the greedy military's mobility demands, partly because of negative effects on employment, and as they require their husbands to absorb more of the burden of moving, the military is faced with pressures to change.

Let us now consider actual and potential military adaptations to changes in military families, paying particular attention to their implications for institutional and occupational trends in the military. 


\section{Military Adaptations to Military Families}

Prototypical greedy institutions ensure the undivided loyalty of their members by normatively restricting outside social relationships from developing. The American military in the past limited the family ties of some of its personnel and continues to do so in various ways. Most notable is the exclusion from the service academies of anyone who is married or a parent. Control over the daily lives of enlisted personnel in basic training or boot camp restricts their contact with family members. Unaccompanied tours, while not prohibiting family ties, discourage personnel from bringing their families. During certain times of conscription, such as the early Vietnam years, drafting only young men and allowing exemptions based on family responsibilities limited the number of personnel with spouses and childern.

Despite these mechanisms, the proportion of married military personnel has increased. This trend began even before the all-volunteer force was instituted in 1973 and has grown since then; given both the declining size of youth cohorts and public opinion regarding draft exemptions, it is unlikely that even a return to conscription would reverse it. Nor does it necessarily harm the military to have more soldiers with families. It can be beneficial; for example, married soldiers have fewer disciplinary problems than single ones. Thus, the military institution has to adapt to the family patterns of its personnel. Such adaptation in the traditional military does not necessarily result in shifts toward occupational forms of service life; rather, some adaptations can preserve, or even heighten, institutional commitment.

Recruitment, morale, and retention of military personnel are affected by family members' attitudes toward the military lifestyle. ${ }^{83}$ Thus, the armed forces have been concerned with the quality of family life and must continue to address changing family patterns. In response to both the recognition of family problems and direct pressures from military family organizations and advocates, the services have been developing family programs and considering potential impacts on families in making personnel policy decisions. The directions of these adaptations can be analyzed for their effects on the institutional nature of military organization. ${ }^{84}$

The military began providing a variety of family support services in the 1960s, and these programs have been expanded in recent years. Organizations such as Army Community Services, the Navy Personal Services Centers, the Air Force Family Support Centers, and other 
organizational subunits offer assistance directly to families, which includes legal advice, family counseling, financial help, English classes for foreign-born spouses, and relocation assistance. The last mentioned includes advance information about the area and installation to which a service member is being transferred, assigned sponsors at the new location, and temporary loans of household items. "Family advocacy" programs have been established to prevent and treat cases of family violence (child and spouse abuse) ${ }^{85}$

Among the organizations and activities affecting military family policies is the National Military Family Association (originally named the National Military Wives Association), which acts as an advocate for military families in the services and in Congress. The Army Family Action Committee, with the support of the Army Officers Wives Club of the Greater Washington Area and the Association of the United States Army, and later the Army itself, organized several Army Family Symposia in Washington, D.C., in the early 1980s. These meetings brought together family representatives from Army installations all over the world to discuss problems, share information on effective family support programs, and make recommendations to the Army.

Responses of the military to family concerns and pressures include establishment of a family adviser to the Assistant Secretary of Defense for Manpower, Installations, and Logistics. The Army Office of the Deputy Chief of Staff for Personnel has a Family Liaison Office to represent family concerns. The Army Chief of Staff declared 1984 the Year of the Family.

Although the programs developed have not yet created major institutional changes in the demands the military makes on service members and their families, they have established mechanisms for identifying and addressing areas where change is desirable and possible, and voices within the military organization represent family concerns.

There are several major areas of concern, considered earlier in this paper, where military adaptation can potentially increase the institutional commitment of service members and their families. These include junior enlisted families, spouse employment, military women, and dualservice couples.

The special circumstances of young enlisted families place them at high risk for a host of problems, including poverty, family violence, psychological adjustment difficulties, and marital dissolution. There are potential policies that can ease their burdens while at the same time integrating them into the military institution. For example, provision of on-post housing can relieve some of their financial pressures, facilitate 
their use of available on-post services, and socialize them to the military way of life. Further, even without providing on-post housing, the armed forces can offer opportunities for junior enlisted families to develop informal social support networks, which ameliorate the effects of stressful life events. Personnel policies such as the Army's unit rotation can facilitate these opportunities if the units make specific attempts to do so. Incorporating enlisted wives into the military organization in ways similar to the institutionalization of the roles of officers' wives can potentially strengthen their husbands' commitment to the military. Indeed, the direction of social change with regard to women's roles, and the effects of social class on these changes, may presage more integration into post life for enlisted wives and less for officers' wives.

The services have begun to accommodate the employment needs of military spouses, but much remains to be done. Among the policies that can be beneficial are longer tours in one location, job banks, education and job training services, expanded child-care facilities, and coordination with civilian employers (including those overseas near military installations). Further, the armed forces need to actively oppose local hiring policies that discriminate against military spouses, even for government jobs in the military community, because these policies seriously impede employment.

The increases in women in uniform have already required changes in the traditionally male military institution. Such organizational adaptations, however, do not make the military any less of an institution. Military women generally enter the armed forces for the same reasons as men. Indeed, they may be even more institutionally committed than men because women, socialized to subjugate their individual goals to group goals, in general are often found to be more service and collectivity oriented. However, the morale and career commitments of military women are affected by their treatment within the organization. It is beyond the scope of this paper to discuss all the ways to improve the integration of women in the military. But specifically regarding family issues, given that the family is normatively greedier for women, service policies can aim at being partially accommodating to especially greedy family stages. Thus, for example, military members can be allowed to take parental leave, and child-care programs can be improved.

The potentially high commitment of dual-service couples has already been noted. To retain these couples, the major effort required by the military is the provision of coordinated assignments. Although this gets more difficult as the numbers of such couples increase, the gains in institutional dedication may be worth the accommodations necessary. 
In general, the more the military services adapt to family needs, the more committed will be both service members and their families to the institution. Family quality of life and satisfaction with the military can be improved by such policies as, when possible, taking family desires into account in the timing of relocation, giving advance notice of transfers, and providing various forms of assistance when separations are necessary.

The more the military's actions make service members and their families truly hear and believe the message that "the military takes care of its own," the less will be the conflict between the two greedy institutions of the military and the family. To the extent that the military views the family as an outside influence with which it competes, the military will likely move in an occupational direction. To the extent that the military works to incorporate the family within itself and adapts to it, the result will be institutional change but preservation of the institutional nature of military organization.

\section{Notes}

1. Lewis A. Coser, Greedy Institutions: Patterns of Undivided Commitment (New York: The Free Press, 1974).

2. Charles C. Moskos, "From Institution to Occupation," Armed Forces \& Society 4 (Fall 1977): pp. 41-50; Charles C. Moskos, "The All-Volunteer Military: Calling, Profession, or Occupation?" Parameters 7 (1977): pp. 2-9; Charles C. Moskos, "The Emergent Military: Calling, Profession, or Occupation?" in The Changing World of the American Military, ed. Franklin D. Margiotta (Boulder, Colo.: Westview Press, 1978), pp. 199-206; Charles C. Moskos, "Institutional/ Occupational Trends in Armed Forces: An Update," Armed Forces \& Society 12, 3 (Spring 1986): pp. 377-382.

3. Coser, Greedy Institutions, p. 1.

4. Ibid., p. 4.

5. Ibid., p. 2.

6. Ibid.

7. Ibid., p. 4.

8. Ibid., p. 6.

9. Erving Goffman, Asylums: Essays on the Social Situation of Mental Patients and Other Inmates (Garden City, N.Y.: Doubleday \& Company, 1961), p. xiii.

10. Ibid., p. 5.

11. Coser, Greedy Institutions, p. 6.

12. 3 (Spring 1986): pp. 377-382.

13. Lewis Coser and Rose Laub Coser, "'The Housewife and Her 'Greedy Family,' , in Coser, Greedy Institutions, pp. 89-100. 
14. Ibid., p. 89.

15. Ibid., p. 92.

16. Ibid., p. 99.

17. Ibid., p. 100 .

18. Ibid.

19. For reviews of research and annotated bibliographies on military families, see Willard M. Bennett et al., Army Families (Carlisle Barracks, Pa.: U.S. Army War College, 1974); Susan Farish, Francoise Baker, and Marilyn Robertson, "Research on the Military Family: An Annotated Bibliography,' in Families in the Military System, ed. Hamilton I. McCubbin, Barbara B. Dahl, and Edna J. Hunter (Beverly Hills, Calif.: Sage, 1976); Edna J. Hunter, Families Under the Flag: A Review of Military Family Literature (New York: Praeger, 1982); Edna J. Hunter, Donald Den Dulk, and John W. Williams, The Literature on Military Families, 1980: An Annotated Bibliography (Colorado Springs, Colo.: U.S. Air Force Academy, TR No. 80-11, 1980); Military Family Resource Center, Review of Military Family Research and Literature, vol. 1: Review, vol. 2: Annotated Bibliography (Springfield, Va.: Military Family Resource Center, 1984).

20. Zahava D. Doering and William P. Hutzler, Description of Officers and Enlisted Personnel in the U.S. Armed Forces: Reference for Military Manpower Analysis (Santa Monica, Calif.: RAND, March 1982), p. 161. The 1978-79 survey contains the most recent comprehensive data publicly available. While rates of occurrence of some organizational demands may have changed somewhat since the survey was conducted, it is unlikely that the changes are large enough to affect any of the conclusions being drawn here. Indeed, these data can serve as a baseline to map changes in the demands on service members and their families.

21. Ibid., pp. 160-161.

22. Ibid., pp. 168-169.

23. See, for example, Jerry L. McKain, "Alienation: A Function of Geographical Mobility among Families,"' in McCubbin, Dahl, and Hunter, eds., Families in the Military System, pp. 69-91; Mady Wechsler Segal, "Enlisted Family Life in the U.S. Army: A Portrait of a Community,'" in Life in the Rank and File: Enlisted Men and Women in the Armed Forces of the United States, Australia, Canada, and the United Kingdom, ed. David R. Segal and H. Wallace Sinaiko (Washington, D.C.: Pergamon-Brassey's, 1986), pp. 184-211; John D. Woelfel and Joel M. Savell, "Marital Satisfaction, Job Satisfaction, and Retention in the Army," in Military Families: Adaptation to Change, ed. Edna J. Hunter and D. Stephen Nice (New York: Praeger, 1978), pp. 17-31.

24. See, for example, Department of the Army, Soldiers Report III: 1984 (Washington, D.C.: Human Resources Development Directorate, Office of the Deputy Chief of Staff for Personnel, U.S. Department of the Army, 1984), pp. 8-8 to 8-9.

25. Descriptions such as these of the various reactions of some military family members to the organizational demands are derived from several sources, including literature on military families in general, observations of military family members' behavior, and research interviews conducted by the author with military families and with people who provide services (including mental health services) to them.

26. Paul Darnauer, "The Adolescent Experience in Career Army Families," in McCubbin, Dahl, and Hunter, eds., Families in the Military System, pp. 42-66. 
27. Department of the Army, Soldiers Report, p. 8-7; Allyson S. Grossman, The Employment Situation for Military Wives (Washington, D.C.: U.S. Department of Labor, Bureau of Labor Statistics, 1984).

28. Tom Burgess, "Three Military Wives Jobless for Every Civilian One in U.S.," Army Times, 5 November 1984, pp. 3, 66.

29. For data on costs of moving, as well as perceptions of other problems associated with moving, see Doering and Hutzler, Officers and Enlisted Personnel, pp. 160-245.

30. Reuben Hill, "Foreward," in McCubbin, Dahl, and Hunter, eds., Families in the Military System, p. 13.

31. Doering and Hutzler, Officers and Enlisted Personnel, from data in tables on pp. 130-131.

32. Ibid., pp. 161-171.

33. See, for example, Elwood Carlson and Ruth Carlson, Navy Marriages and Deployment (Lanham, Md.: University Press of America, 1984); Kathryn Brown Decker, "Coping with Sea Duty: Problems Encountered and Resources Utilized During Periods of Family Separation," in Hunter and Nice, eds., Military Families, pp. 113-129; Frank Flores Montalvo, "Family Separation in the Army: A Study of the Problems Encountered and the Caretaking Resources Used by Career Army Families Undergoing Military Separation,' in McCubbin, Dahl, and Hunter, eds., Families in the Military System, pp. 147-173; D. Stephen Nice, "The Course of Depressive Affect in Navy Wives During Family Separation"' (San Diego, Calif.: Naval Health Research Center, 1979); Alice Ivey Snyder, Sea and Shore Rotation: The Family and Separation: A Bibliography of Relevant Material (Pearl Harbor, Hawaii: Mental Health Clinic, Naval Regional Medical Clinic, 1977); E. W. Van Vranken et al., "The Impact of Deployment Separation on Army Families" (Washington, D.C.: Walter Reed Army Institute of Research, Report NP-84-6, 1984).

34. For a review of some of this literature, see Hunter, Families Under the Flag, pp. 44-50; Military Family Resource Center, Review, pp. 31-35.

35. Edna J. Hunter, "Marriage in Limbo," Proceedings, U.S. Naval Institute, vol. 108/7/953 (July 1982): pp. 27-32. See also Hamilton I. McCubbin et al., Family Separation and Reunion: Families of Prisoners of War and Servicemen Missing in Action (San Diego, Calif.: Naval Health Research Center, Center for Prisoner of War Studies, Report No. 74-70, 1974); Alice Stratton, “'The Stress of Separation," U.S. Naval Institute Proceedings 104 (July 1978): pp. 53-58.

36. Reuben Hill, Families Under Stress: Adjustment to the Crisis of War Separation and Reunion (New York: Harper and Bros., 1949); Hamilton I. McCubbin and Barbara B. Dahl, "Prolonged Family Separation in the Military: A Longitudinal Study," in McCubbin, Dahl, and Hunter, eds., Families in the Military System, pp. 112-144.

37. Department of Defense, Defense 84 Almanac (September 1984): pp. 26-27.

38. Doering and Hutzler, Officers and Enlisted Personnel, pp. 180-194.

39. For a review of the literature on overseas living and its effects, see Military Family Resource Center, Review, pp. 119-124.

40. Moskos, “Institutional/Occupational Trends,", p. 381. 
41. Nancy Shea (and revised by Anna Perle Smith), The Army Wife (New York: Harper \& Row, 1941 to 1966).

42. Ibid., p. 1.

43. Ibid., pp. 69-71.

44. Ibid., p. 55.

45. Ibid., p. 75.

46. Nancy L. Goldman, "Trends in Family Patterns of U.S. Military Personnel During the 20th Century," in The Social Psychology of Military Service, ed. Nancy L. Goldman and David R. Segal (Beverly Hills, Calif.: Sage, 1976), pp. 119-120.

47. Ibid., pp. 120-123.

48. Ibid., p. 124.

49. Doering and Hutzler, Officers and Enlisted Personnel, from data on pp. 96, 101.

50. Goldman, "Trends in Family Patterns."

51. Ibid.

52. Doering and Hutzler, Officers and Enlisted Personnel, p. 96: this includes women as well as men.

53. Ibid., pp. 96-100.

54. U.S. Census Bureau, as reported in Department of the Army, Soldiers Report.

55. Doering and Hutzler, Officers and Enlisted Personnel, p. 101.

56. Nancy Goldman, "The Changing Role of Women in the Military," American Journal of Sociology 79 (1973): p. 895.

57. Department of Defense, Defense 84 Almanac, p. 31.

58. Richard J. Brown III, Richard Carr, and Dennis K. Orthner, "Family Life Patterns in the Air Force," in Changing U.S. Military Manpower Realities, ed. Franklin D. Margiotta, James Brown, and Michael J. Collins (Boulder, Colo.: Westview Press, 1983), pp. 207-220; Doering and Hutzler, Officers and Enlisted Personnel; Dennis K. Orthner and Rosemary S. Nelson, “A Demographic Profile of U.S. Navy Personnel and Families" (Prepared for Department of the Navy, Navy Family Support Program, August 1980).

59. Orthner and Nelson, "Navy Personnel and Families," p. 24.

60. Brown, Carr, and Orthner, "Family Life Patterns.'

61. Doering and Hutzler, Officers and Enlisted Personnel, pp. 282-291.

62. Department of the Army, Soldiers Report, p. 8-16.

63. Ibid., p. 8-17.

64. Orthner and Nelson, "Navy Personnel and Families," p. 24.

65. Ibid.

66. Ibid.

67. All data in this paragraph are from Brown, Carr, and Orthner, "Family Life Patterns," p. 213.

68. Department of the Army, Soldiers Report, p. 8-17. 
69. Brown, Carr, and Orthner, “Family Life Patterns," pp. 213-214.

70. Ibid., p. 214.

71. Dennis K. Orthner, Families in Blue: A Study of Married and Single Parent Families in the U.S. Air Force (Washington, D.C.: Office of the Chief of Chaplains, U.S. Air Force, 1980), p. 12.

72. Waivers of the automatic discharge for pregnancy were provided beginning in 1971. By 1973, the services were approving most waiver requests. A DoD-directed policy of voluntary separations took effect in 1975. For a chronicle of these policy changes, see Jeanne Holm, Women in the Military: An Unfinished Revolution (Novato, Calif.: Presidio Press, 1982), pp. 289-304.

73. Doering and Hutzler, Officers and Enlisted Personnel, p. 95.

74. Orthner and Nelson, "Navy Personnel and Families," p. 27.

75. Ibid., p. 29.

76. Orthner, Families in Blue, p. 13.

77. Ibid.

78. Doering and Hutzler, Officers and Enlisted Personnel, pp. 282, 287.

79. Department of the Army, Soldiers Report, p. 8-6, using data from U.S. Department of Labor, Bureau of Labor Statistics, Monthly Labor Review, February 1981 and updated information from Ms. Waldman.

80. Ibid., p. 8-7.

81. Burgess, "Three Military Wives Jobless.",

82. Coser and Coser, "The Housewife," p. 97.

83. For a review of the literature, see Military Family Resource Center, Review, pp. 20-25.

84. While the focus of this paper is on American military families, it is interesting to note increased research and policy attention to military families in other Western nations and research findings similar to many reported here. See, for example, on Australia: N.A. Jans, "Issues in Australian Service Family Life-An Empirical Study" (Mimeo) and Careers in Conflict: A Study of Service Officers Careers and Families in Peacetime (forthcoming); on the Federal Republic of Germany: Heidelore Dillkofer, Georg-Maria Meyer, and Siegfried Schneider, Soziale Probleme von Soldatenfamilien der Bundeswehr (with English summary) (München: Sozialwissenschaftliches Institut der Bundeswehr, 1985); on France: Chantal Laharanne, "The French Army NCO's Wife: From Dependence to Interdependence through Negotiation"' (Paper prepared for the International Conference of the Inter-University Seminar on Armed Forces and Society, Chicago, Ill., October 1983).

85. For a history and description of these programs, see Gary Lee Bowen, "Military Family Advocacy: A Status Report," Armed Forces \& Society 10, 4 (Summer 1984): pp. 583-596.

MADY WECHSLER SEGAL is an associate professor of sociology at the University of Maryland and a guest scientist in the Department of Military Psychiatry at the Walter Reed Army Institute of Research. She has been conducting research on military families since 1973 and teaches a course on military families. Her current research focuses on stability and change in Army communities. 